\title{
Effectiveness of Planned Teaching Program on Knowledge Regarding Effects of Alcoholism among Adults
}

\author{
Sah $\mathbf{I}^{1 *}$, Dangol SM ${ }^{2}$
}

'Lecturer, College of Nursing Sciences, Gandaki Medical College, Pokhara, Nepal

${ }^{2}$ Lecturer, School of Nursing and Midwifery, Patan Academy of Health Sciences, Sanepa, Lalitpur, Kathmandu, Nepal

\section{Keywords}

Effects of alcoholism, Knowledge,

Planned Teaching Program.

\section{Corresponding author}

*Ms Indu Sah

M.Sc Nursing, Lecturer

College of Nursing Sciences

Gandaki Medical College, Pokhara, Nepal

Email:indukali58@gmail.com

\section{ABSTRACT}

Background: Alcoholism is chronic progressive and often fatal disease. It is a primary disorder and not a symptom of other disease or emotional problems. The chemistry of alcohol allows it to effect nearly every type of cell in the body, including those in the central nervous system.

Objectives: The main objectives of this study are 1) to assess the level of knowledge regarding effects of alcohol among rural adults, 2) to assess the post test knowledge regarding effects of alcohol among rural adults, and 3) to evaluate the effectiveness of planned teaching program on knowledge regarding effects of alcoholism.

Methods: A Quasi-experimental one group pre-test post-test research design was adopted for the present study. The structured interview schedule was developed to collect data. The study was conducted at Challaghatta Village, Bangalore, Karnataka State, India and the data collected was analyzed and interpreted based on descriptive and inferential statistics.

Results: The assessment of knowledge level of adults regarding effects of alcoholism revealed that the mean pretest was 9.6 with SD 3.06. Mean post-test was 20.04 with SD 1.6 and enhancement mean score 10.8 with SD 1.08 and paired $t$ value 9 which shows statistically significant at $p$ $>0.05$ level.

Conclusion: The present study attempted to assess the effectiveness of planned teaching program (PTP) on knowledge of rural adults regarding effects of alcoholism and found that the developed PTP was effective in improving the knowledge of rural adults regarding effects of alcoholism.

\section{INTRODUCTION}

Alcoholism is a significant problem all over the world. Chronic alcoholism causes severe health problem like liver disorder, gastrointestinal problem, diabetes, skin, muscle, bone disorder and reproductive problem. Prolonged heavy use of alcohol can lead to addiction ${ }^{1}$.

Extensive alcohol intake is likely to produce withdrawal symptoms including severe anxiety, tremor, hallucination and convulsion. In addition mother who drinks alcohol during pregnancy may give birth to infant with fetal alcoholic syndrome. These infant may suffer from mental retardation and other irreversible physical abnormality ${ }^{2}$.

Drinking is considered harmful when alcohol consumption has actually caused physical or psychological harm. People with alcohol abuse have one or more of the alcohol-related problems over a period of one year like failure to fulfill work or personal obligations, recurrent use in potentially 
dangerous situations ${ }^{3}$.

Alcoholism (alcohol dependence) is a chronic illness marked by dependence on alcohol consumption. It interferes with physical or mental health, and social, family or job responsibilities. This addiction can lead to liver, circulatory, and neurological problems ${ }^{4}$.

\section{METHODS}

A quantitative research approach was considered most suitable for this study, as the objective was to find out the knowledge regarding effects of alcoholism among adults, Quasi-experimental one group pre-test post-test design ${ }^{5}$ was used to assess the effectiveness of planned teaching program.

Table 1: Schematic representation of Research design

\begin{tabular}{cccc}
\hline Group & Pre-test & $\begin{array}{c}\text { Nursing interven- } \\
\text { tion }\end{array}$ & Post-test \\
Adults & $\begin{array}{c}\text { Structured inter- } \\
\text { view schedule }\end{array}$ & $\begin{array}{c}\text { Planned teaching } \\
\text { program }\end{array}$ & $\begin{array}{c}\text { Structured } \\
\text { interview schedule }\end{array}$ \\
\hline
\end{tabular}

\section{Variables}

1. Dependent variables: The level of knowledge regarding effects of alcoholism among rural adults.

2. Independent variables: "Planned Teaching Programs " regarding effects of alcoholism among rural adults

\section{Study setting}

The study was conducted in selected rural community namely Sullikere, komaghatta village under Sullikere primary health centre, Bangalore, Karnataka State, India among the rural adults aged between 20 - 50 years, with sample size of 20. Simple random sampling technique was used for selection of samples.

\section{Plan for data analysis}

Data collected was analyzed by using descriptive and inferential statistics

\section{Descriptive statistics}

Range, mean, standard deviation and mean percentage was used to assess the level of knowledge regarding effects of alcoholism in rural adults.

\section{Inferential statistics}

Paired t test was used to compare the pre-test and post- test level of knowledge regarding the effects of alcoholism among adults.

\section{RESULTS}

\section{Organization and Presentation of data}

Section 1: Assessment of level of knowledge regarding effects of alcoholism

Section 2: Assessment of effectiveness of planned teaching program on knowledge regarding effects of alcoholism among rural adults

\section{Presentation of data}

Section 1: Assessment of level of knowledge regarding effects of alcoholism

Table 1(a): Assess the pre-test level of knowledge regarding the effects of alcoholism among rural adults in selected rural community, Bangalore, India $(n=20)$

\begin{tabular}{lcccccc}
\hline Domain & \multicolumn{3}{c}{$\begin{array}{c}\text { Level of knowledge } \\
(>50)\end{array}$} & $\begin{array}{c}\text { Moderate } \\
(50-75)\end{array}$ & \multicolumn{2}{c}{$\begin{array}{c}\text { Adequate } \\
(<75)\end{array}$} \\
Knowledge & No & $\%$ & No & $\%$ & No & $\%$ \\
& 16 & 80 & 4 & 20 & 0 & 0 \\
\hline
\end{tabular}

Table 1(a) shows the assessment of the pre-test level of knowledge in that $16(80 \%)$ are having inadequate knowledge and four (20\%) are having moderate knowledge regarding effects of alcoholism.

Table 1(b): Assessment of the mean and the standard deviation of pre-test level of knowledge regarding effects of alcoholism among rural adults $(n=20)$

\begin{tabular}{llllll}
\hline Domain & $\begin{array}{l}\text { Max. } \\
\text { score }\end{array}$ & Range & Mean & SD & Mean \% \\
\hline Pre-test & 17 & $6-17$ & 9.6 & 3.04 & 48 \\
\hline
\end{tabular}

This table 1(b) shows that mean and standard deviation of effects of alcoholism among rural adults. In that mean is 9.6 and standard deviation is 3.04.

Table 2(a): Assessment of the post-test level of knowledge regarding effects of alcoholism among rural adults in selected rural community $(n=20)$

\begin{tabular}{|c|c|c|c|c|c|c|}
\hline Domain & \multicolumn{6}{|c|}{ Level of knowledge } \\
\hline \multirow{3}{*}{ knowledge } & & $\begin{array}{l}\text { quate } \\
\text { 50) }\end{array}$ & \multicolumn{2}{|c|}{$\begin{array}{l}\text { Moderate } \\
(50-75 \%)\end{array}$} & \multicolumn{2}{|c|}{$\begin{array}{c}\text { Adequate } \\
(>75 \%)\end{array}$} \\
\hline & No & $\%$ & No & $\%$ & No & $\%$ \\
\hline & 0 & 0 & 0 & 0 & 20 & $100 \%$ \\
\hline
\end{tabular}


Table 2(a) shows the assessment of the post test level of knowledge in that $20(100 \%)$ are having adequate knowledge regarding effects of alcoholism.

Table 2(b): Assessment of the mean and the standard deviation of post-test level of knowledge regarding effects of alcoholism among rural adults $(n=20)$

\begin{tabular}{llcclc}
\hline Domain & $\begin{array}{l}\text { Max. } \\
\text { score }\end{array}$ & Range & Mean & $\begin{array}{l}\text { Standard } \\
\text { Deviation }\end{array}$ & Mean \% \\
$\begin{array}{l}\text { Post- } \\
\text { test }\end{array}$ & 23 & $17-23$ & 20.4 & 1.6 & 102 \\
\hline
\end{tabular}

This table 2(b) shows that mean and standard deviation of effects of alcoholism among rural adults. In that mean is 20.4 and standard deviation is 1.6

Fig 1: Comparison of percentage distribution of adults according to pre-test and post-test level of knowledge

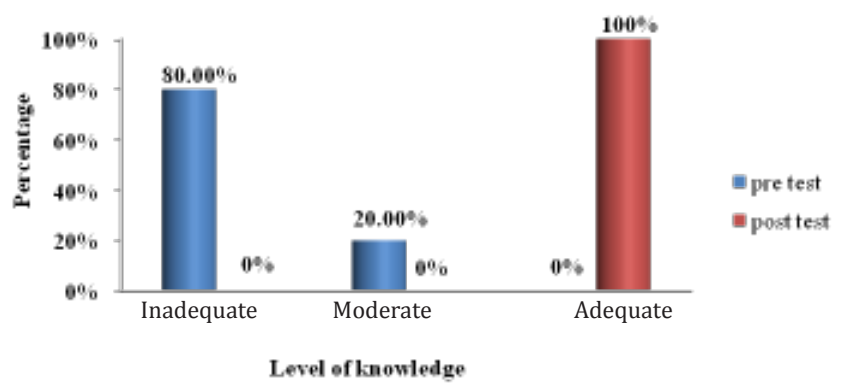

Section 2: To evaluate the effectiveness of planned teaching program on knowledge regarding effects of alcoholism among rural adults

Table 3: Effectiveness of planned teaching program on knowledge regarding the effects of alcoholism among rural adults $(n=20)$

\begin{tabular}{|c|c|c|c|c|c|c|c|}
\hline \multirow[t]{2}{*}{ Domain } & \multicolumn{2}{|c|}{ Pre test } & \multicolumn{2}{|c|}{ Post test } & \multicolumn{2}{|c|}{ Enhancement } & \multirow{2}{*}{$\begin{array}{l}\text { Paired } \\
\text { ' } t \text { ' test }\end{array}$} \\
\hline & Mean & SD & Mean & SD & Mean & SD & \\
\hline Knowledge & 9.6 & 3.04 & 20.4 & 1.6 & 10.8 & 1.08 & 9 \\
\hline
\end{tabular}

This Table 3 shows that enhancement means 10.8 and SD is 1.08 and paired t value is 9 . It shows that statistically significant at $\mathrm{p}>0.05$ level.

\section{DISCUSSION}

Present study aims to assess the effectiveness of planned teaching program on knowledge regarding effects of alcoholism among adults which shows the assessment of the pretest level of knowledge in that 16 members (80\%) are having inadequate knowledge and four members (20\%) are having average knowledge regarding effects of alcoholism.

The findings are consistent with the study conducted by Godley SN, Williams $\mathrm{JK}^{10}$. They concluded that the knowledge of rural adults about the topic alcohol and alcoholism is very less compared to urban area.

The similar study was conducted regarding alcohol use and its harmful effects among high school children at Municipal Corporation School in Tirupati, Andhra Pradesh, India. The study findings revealed that among 60 high school children 15 (25\%) had inadequate knowledge, 24 (40\%) had moderate knowledge and 21 (35\%) had adequate knowledge in pretest after administration of structured teaching program, the posttest findings revealed that eight $(13.3 \%)$ had inadequate knowledge 28 (46.7\%) had moderate knowledge and 24 (40\%) had adequate knowledge which indicates that the high school children had gained knowledge on alcohol use and its harmful effects after the structured teaching program ${ }^{6}$.

A similar study conducted to assess the knowledge and attitude of 50 pre university students regarding effect of alcohol in Chamarajpet, Bangalore, India by simple random technique. The data was collected by using knowledge questionnaire. The study revealed that $33.2 \%$ students had inadequate knowledge about effect of alcohol. The study concluded by recommendation of an effective teaching intervention for the students to improve knowledge on adverse effects of alcoholism ${ }^{7}$.

A study was conducted to assess the effectiveness of street play on alcoholism among 50 young adults regarding alcoholism in Raichur, Karnataka State, India by simple random sampling. The structured interview schedule was used for the data collection. The study revealed that the mean of overall knowledge score in pre test was increased from 19.4 to 28.6 in post test ${ }^{8}$.

In our study the findings of the posttest level of knowledge is $20(100 \%)$ are having adequate knowledge regarding effects of alcoholism after the planned teaching program. Table 3 shows that enhancement mean 10.8 and SD is 1.08 and paired $t$ value is 9 . It shows that statistically significant at $\mathrm{p}>0.05$ level. Based on the findings planned teaching program was found to be effective in improving the knowledge regarding effects of alcoholism among adults.

The findings of our study have been supported by a similar study which was conducted on improvement of 
knowledge, attitude and behavior about oral health in a population of alcohol addicted persons. The study helps to improve the knowledge, attitude about oral health and oral cancer prevention in a population of alcohol addicted persons. A pre post test questionnaire was used to assess the short time effectiveness among 76 individuals. At one year from the intervention, 42 participants who reached follow up showed a great improvement in knowledge and attitude towards oral health ${ }^{9}$.

\section{Limitations of the study}

1. Time constraint is a limitation as a researcher took 20-30 minutes to interview each sample

2. Difficulty to establish rapport and cooperation from some family members.

\section{CONCLUSION}

The study was conducted to assess the level of knowledge regarding the effects of alcoholism among the rural adults in the selected rural community, in that, 16 members (80\%) were having inadequate knowledge and 4 members (20\%) were having average knowledge regarding effects of alcoholism before the planned teaching program but after the intervention 20 members $(100 \%)$ were having adequate knowlegdge regarding effects of alcoholism. This study also attempted to assess the effectiveness of Planned Teaching Program (PTP) on knowledge of rural adults regarding effects of alcoholism and found that the developed PTP was effective in improving the knowledge of rural adults regarding effects of alcoholism.

\section{REFERENCES}

1. "Alcohol Use Disorder: A Comparison between DSM-IV and DSM-5". November 2013; Archived from the original on 18 May 2015.

2. Lankish PG, Sand J. Alcohol consumption in patients with acute or chronic pancreatitis. Pancreatology. 2007; 7(2-3): 147-156.

3. Revathy S. How women cope with alcoholic husbands. The Nursing Journal of India. 2009. April; page no 79-81.

4. Kamala KK. Preventing drug abuse and teaching. Health Action. June 2006; page no 33-35.
5. Basavanthappa BT. Nursing Research. New Delhi. Jaypee publications. (1998). First edition. Page no $262-268$.

6. Snehalatha R, Bhagyalakshmi M, Hemalatha S. A Study to assess the effectiveness of structured teaching program on knowledge regarding alcohol use and Its harmful effects among high school children at Municipal Corporation School in Tirupati. New York, Penguin. J Drug Abuse. 2017; Vol 3 No 3: 25.

7. Ravindrakumar KV. A study on knowledge and attitude towards the effects of alcohol among the students in a selected Pre-University college, Bangalore with view to develop an information guide sheet on prevention of alcoholism. Unpublished Masters of Nursing Thesis. Bangalore: Rajiv Gandhi University of Health Sciences. 2006.

8. Dhandagri. UN. Effectiveness of street play on Alcoholism. Nightingale Times. Aug 2009; 5(5): 50-2.

9. Amninoi, Barbadoro P. Improvement of knowledge, attitude and behavior about oral health in alcohol addicted persons. Alcohol. 2008 May; 43(30): 347-350.

10. Godley SN, Williams JK. Disseminating evidencebased practices in substance abuse treatment. Journal of Substance Abuse Treatment. 2006; 31(1): 25-39. 